\title{
KONSTRUKSI YURIDIS HYBRID CONTRACT DALAM PEMBIAYAAN TAKE OVER KPR PADA PERBANKAN SYARIAH
}

\author{
Kholid Albar \\ Moch. Tolchah \\ e-mail: albarkholid46@gmail.com
}

\begin{abstract}
In the process of the occurrence of hybrid contract in the process of take over of course the bank which in this case is sharia banking will certainly experience the risks in the financing that is influenced by several factors including the rate of inflation so that it also affects the liquidity of sharia banking itself, today due to the liquidity of sharia banking largely depends on the acquisition of third party funds either in the form of investment account or current account which will be channeled into financing according to sharia, such as mudharabah, musyarakah, murabaha, salam, isthisna and ijarah which can generate profit sharing margin which is the main profit source (income) of sharia banks. Lack of liquidity will cause banks to bankruptcy quickly, whereas if excess liquidity is also dangerous is a low probability that leads to the same thing. So the risk of liquidity will be a consideration for depositors to choose which bank for customers save funds. Because the purpose of this study, First to determine the effect of hybrid contract variables, inflation rate and concepts of profit sharing simultaneously and partially to liquidity risk in Islamic banking.
\end{abstract}

Keywords : Hybrid Contract, Take Over dan Syariah Bank

\section{PENDAHULUAN}

Pemenuhan kebutuhan setiap manusia berbeda-beda. Salah satu yang menyebabkan perbedaan tersebut adalah pendapatan yang didapat oleh masing-masing pribadi. Harga rumah yang begitu tinggi menyebabkan tidak semua orang mampu membelinya secara tunai. Dewasa ini, pembiayaan hunian yang ditawarkan oleh berbagai bank kadang menjadi jalan keluar bagi orang-orang yang menginginkan sebuah hunian dengan cara mencicil ke bank yang memberikan fasilitas pembiayaan hunian tersebut. Bank syariah pun mulai mengembangkan fasilitasnya hingga kepada pembiayaan hunian syariah.

Rumah adalah bangunan gedung yang berfungsi sebagai tempat tinggal yang layak huni, sarana pembinaan keluarga, cerminan harkat dan martabat penghuninya, serta aset bagi pemiliknya.Perspektif Islam mengenal konsep rumahkusurgaku (baiti jannat). Rumah selain simbol bagi status ekonomi seseorang di dalam masyarakat, namun berperan juga membentuk karakter, akhlak, serta kepribadian bangsa. Sebagaimana yang terdapat dalam Surat Al-Baqarah ayat 125 yang artinya: "Dan (ingatlah), ketika Kami menjadikan rumah (Ka'bah) tempat berkumpul dan tempat yang aman bagi manusia. Dan jadikanlah maqam Ibrahim itu tempat sholat. Dan telah kami perintahkan kepada Ibrahim dan Ismail, "Bersihkanlah rumah-Ku untuk orang-orang yang tawaf, orang yang itikaf, orang yang rukuk, dan orang yang sujud!” 
Perbankan dan lembaga
keuangan syariah harus bisa memenuhi kebutuhan bisnis modern dengan menyajikan produk-produk inovatif dan lebih variatif serta pelayanan yang memuaskan sesuai dengan tuntutan bisnis modern. Tantangan ini menuntut para praktisi, regulator, konsultan, dewan syariah dan akademisi bidang keuangan syariah untuk senantiasa aktif dan kreatif dalam memberikan respon terhadap loncatan-loncatan dan perkembangan bentuk bisnis tersebut.

Salah satu strategi pemasaran yang dikembangkan oleh bank-bank saat ini adalah dengan pengalihan (take over) pembiayaan hunian syariah. Take over pembiayaan hunian adalah pemindahan fasilitas pembiayaan yang berjalan disuatu bank ke pembiayaan bank lain. Pengambilalihan ini hanya untuk sisa pokok pinjaman nasabah dari bank pemberi pembiayaan pertama, yang dilanjutkan dengan mencicil sisa pokok pinjaman ke bank yang mengambilalih pembiayaannya. Take over dapat dilakukan sesama bank konvensional atau sesama bank syariah, maupun dari bank konvensional ke bank syariah ataupun sebaliknya.

Take over adalah salah satu pelayanan bank syariah dalam membantu masyarakat mengalihkan transaksi non syariah yang telah berjalan menjadi transaksi yang sesuai dengan syariah sesuai dengan pemintaan nasabah. Dalam implementasinya, upaya pengembangan perbankan syariah memerlukan aturan-aturan syariah yang mengikat bagi perbankan syariah. Dalam kaitan ini, fatwa yang $\mathrm{t}^{1}$ erkait dengan perbankan syariah dikeluarkan Dewan Syariah Nasional-Majelis Ulama Indonesia (DSN-MUI), fatwa tersebut sangat bernilai dan berperan besar sebagai referensi utama dalam proses penyusunan peraturan Bank Indonesia bagi perbankan syariah (Muhammad: 2004). Transaksi perpindahan take over pembiayaan dari bank konvensional ke bank syariah diatur dalam fatwa No. 31/DSN-MUI/VI/2002 tentang pengalihan hutang. Dalam fatwa ini disebutkan ada empat alternatif akad yang dapat digunakan yaitu :

1. Qardh dan murabahah

2. Syirkah al-milk dan murabahah

3. Qardh dan ijarah

4. Qardh dan IMBT (ijarah muntahiya bit-tamlik)

Bank syariah saat ini dapat menggunakan ke 4 alternatif di atas untuk melakukan transaksi pembiayaan pengalihan hutang (take over).

Di era transaksi keuangan modern yang semakin kompleks, dibutuhkan design kontrak akad dalam bentuk kombinasi beberapa akad yang disebut dengan hybrid contract (multiakad), atau biasa disebut al-ukud al-murakkabah. Bentuk akad tunggal sudah tidak mampu meresponi transaksi keuangan kontemporer. Kombinasi akad zaman sekarang adalah sebuah keniscayaan, akad tunggal sudah tidak mampu lagi meresponi kasuskasus dan problem keuangan kontemporer. Untuk itu, perbankan syariah harus memperbaiki diri dalam peningkatan kualitas SDM-

\footnotetext{
${ }^{1}$ Adiwarman Karim, 2006, Bank Islam Analisis Fiqih dan Keuangan, Raja Grafindo Persada, Jakarta, hlm, 248
} 
nya dengan melaksanakan training dan workshop intensif mengenai inovasi produk.

Buku-buku teks fikih muamalah kontemporer menyebut istilah hybrid contracts dengan istilah yang beragam, yaitu al-ukudmurakkabah, al-ukud al mujtami'ah, adapula yang menggunakan istilah al-ukud almutajanisah. Menurut istilah fikih, kata hybrid contracts merupakan terjemahan dari kata Arab yaitu al-'uqudal-murakkabah yang berarti akad ganda (rangkap), akad yang bergabung, akad yang berhimpun, akad yang berkombinasi. Al-'uqud al murakkabah terdiri dari dua kata al-'uqud (bentuk jamak dari 'aqd) dan al-murakkabah. Kata 'aqd secara etimologi artinya mengikat, menyambung, atau menghubungkan (ar-rabt). Menurut Syamsul Anwar akad (perjanjian) adalah pertemuan ijab dan kabul sebagai pernyataan kehendak dua pihak atau lebih untuk melahirkan suatu akibat hukum pada objeknya. $^{2}$

Ada beberapa fatwa transaski muamalah yang dikeluarkan oleh Dewan Syariah Nasional (DSN) prihal tentang hybrid contract. Beberapa transaski tersebut antara lain : Fatwa DSN MUI Nomor 31/DSN-MUI/VI/2002 tentang pembiayaan take over atau pengalihan hutang yang memberikan alternatif beberapa akad yang dapat digunakan dalam pembiayan take over ; Fatwa DSN MUI Nomor 54/DSN-MUI/X/2006 tentang syariah card (kartu kredit syariah) dengan menggunakan akad kafalah bil ujrahdan qard wal ijrah; dan Fatwa DSN MUI Nomor 73/DSNMUI/XI/2009 tentang akad

${ }^{2}$ Dewan Syariah Nasional-MUI, 2000, Himpuan Fatwa DSN-MUI, Cet ke-3, edisi revisi, Ciputat: CV.Gaung Persada. musyarokah mutanaqisah yang merupakan kombinasi antara akad musyarakah dan ijarah.

Pada proses terjadinya hybrid contract dalam proses take over tentunya pihak bank yang dalam hal ini adalah perbankan syariah tentunya akan mengalami resikoresiko dalam pembiayaannya yang dipengaruhi oleh beberapa faktor di antaranya adalah tingkat inflasi sehingga hal ini juga berpengaruh terhadap likiditas dari perbankan syariah itu sendiri, dewasa ini dikarenakan likuiditas perbankan syariah sebagian besar sangat tergantung pada perolehan dana pihak ketiga baik berupa investment account maupun current account yang akan disalurkan kedalam pembiayaan sesuai syariah, seperti mudharabah, musyarakah, murabahah, salam, isthisna dan ijarah yang dapat menghasilkan margin bagi hasil yang merupakan sumber profit (pendapatan) utama bank syariah. Kekurangan likuiditas akan mengakibatkan bank mengalami kebangkrutan dengan cepat, sedangkan jika kelebihan likuiditas juga berbahaya yaitu probabilitas yang rendah yang berujung pada hal yang sama. Sehingga resiko likuiditas akan menjadi pertimbangan bagi deposan untuk memilih Bank mana untuk nasabah menyimpan dananya.

Terdapatnya hybrid contract dalam pembiayaan take over menarik minat peneliti untuk mengkaji dan menganalisislebih lanjut mengenai konstruksi yuridis akad-akad dalam tranaksi pembiayaan take over. Hal ini didasari bahwa setiap akad tentunya akan melahirkan hubungan hukum yang berbeda-beda dan menimbulkan hak dan kewajiban diantara para pihak, maka rumusan 
masalah yang diangkat dalam penelitian ini adalah bagaimana konstrksi yuridis hybrid contract dalam pembiayaan take over pada perbankan syariah dan pengaruhnya terhadap resiko likuiditas?

\section{PEMBAHASAN}

Hybrid contract dimaknai secara harfiyah sebagai kontrak yang dibentuk oleh kontrak yang beragam. ${ }^{3}$ Sementara dalam bahasa Indonesia disebut dengan 'Multiakad'. Kata multi dalam bahasa indonesia brarti (1). Banyak; lebih dari satu; lebih dari dua. (2). Berlipat ganda (Tim penyusun, 1996 : 671). Maka dengan demikian 'Multiakad' berati akad ganda atau akad yang banyak, lebih dari satu.

Sedangkan menurut istilah fiqih, kata multiakad merupakan terjemahan dari kata arab yaitu Auqud al-murakkabah yang berarti akad ganda (rangkap). Al-uqud almurakkabah terdiri dari dua suku kata al-uqud (bentuk jamak dari alaqd) yang sudah dijelaskan sebelunya dan al-murakkabah (murakkab) yang secara etimologi berarti al-jam'u, yakni mengumpulkan atau menghimpun (Al-Thanawi, tt : 534). Kata murakkab sendiri berasal dari kata rkkaba-yurakkibu-tarkian yang mengandung arti meletakkan sesuatu pada sesuatu lain sehinnga menumpuk, ada yang di atas danada yang dibawah. (Al-Fairuz, tt : 177). ${ }^{4}$

Nazih Hammad (2005 : 7) mendefinisikan al-adq almurakkabah adalah kesepakatan

\footnotetext{
${ }^{3}$ Tim, penyusun. Kamus besar bahasa indonesia, (jakarta : balai pustaka, 1996), edisi II h. 671

${ }^{4}$ Nazih Hammad, Al-uqud Al-Murakkabah fii al-Fqh al-islami, (Damaskus: Dar AlQalam, 2005), Cet. I h.7
}

antara dua pihak untuk melaksanakan suatu akad yang mengandung dua akad atau lebih (sepertijual beli dengan sewa menyewa, hibah, wakalah, qard, muzara'ah, sahraf (penukaran mata uang), syirkah, mudharabah dan seterusnya. Sehingga semua akibat hukum akadakad yang terhimpun tersebut, serta semua hak dan kewajiban yang ditimbulkannya dipandang sebagai satu kesatuan yang tidak dapat dipisah-pisahkan, sebagaiamana akibat hukum dari satu akad.

Sedangkan murakkab menurut pengertian para ulama fikih adalah: Pertama,himpunan beberapa hal sehingga disebut dengan satu nama. Seseorangmenjadikan beberapa hal menjadi satu hal (satu nama) dikatakan sebagaimelakukan penggabungan (tarkîb). Kedua, sesuatu yang dibuat dari dua ataubeberapa bagian, sebagai kebalikan dari sesuatu yang sederhana (tunggal/basîth) yang tidak memiliki bagian-bagian. Ketiga, meletakkan sesuatu di atassesuatu lain atau menggabungkan sesuatu dengan yang lainnya.Ketiga pengertian ini memiliki kelebihan dan kekurangan masing-masinguntuk menjelaskan makna persis dari istilah murakkab. Pengertian pertamalebih tepat untuk digunakan karena mengandung dua hal sekaligus, yaitu terhimpunnyabeberapa hal dan bersatunya beberapa hal itu yang kemudian menjadisatu pengertian tertentu.

Pengertian kedua tidak
menjelaskan
terhimpunnya
Walaupat beberapahal itu.
Walaupun pengertian kedua
menyatakan adanya gabungan dua
ataubeberapa hal, tetapi tidak
menjelaskan apa dan bagaimana
setelah


penggabungantersebut. Pengertian terakhir lebih dekat kepada pengertian etimologis,tidak menjelaskan pengertian untuk suatu istilah tertentu.

Dengan demikian pengertian pertama lebih dekat dan pas untuk menjelaskanmaksud al-'uqûd almurakkabah dalam konteks fikih muamalah.

'Imrânî, $\quad$ akad $r$ murakkab adalah:Himpunan beberapa akad kebendaan yang dikandung oleh sebuah akad,baik secara gabungan maupun secara timbal-balik, sehingga seluruh hakdan kewajiban yang ditimbulkannya dipandang sebagai akibat hukum darisatu akad.

Selain istilah akad murakkab, ada beberapa istilah lain yang digunakan ahlifikih yang memiliki hubungan, kemiripan, dan kesamaan dengan pengertianakad murakkab. Istilah-istilah itu antara lain al-'uqûd al-mujtami'ah, al-'uqûd almuta'addidah,al-'uqûd almutakarrirah, al-'uqûd almutadâkhilah, al-'uqûd almukhtalithah.Berikut adalah penjelasan pengertian dari beberapa istilah yang miripdengan murakkab ini. Pertama, al-ijtimâ'. Kata ini mengandung arti terhimpunatau terkumpul, lawan dari terpisah. Sesuatu yang terhimpun dari beberapabagian meski tidak menjadi satu bagian adalah arti dari kata ijtimâ'.Denganbegitu al-'uqûd almujtami 'ah berarti terhimpunnya dua akad atau lebih dalamsatu akad.

\footnotetext{
${ }^{5}$ Abd Allah Ibn Muhammad bin Abd Allah al-imrani, Al-uqud al-maliyah alMurakkabah: Dirasah Fiqhiyyah Ta shiliyyah wa Thathbiqiyyah, (Riyadh: Dar Kunuz Eshbelia li al-Nasyr wa alTauzi', 2006) Cet. I, h. 45
}

Sekilas ada persamaan antara istilah murakkab dan mujtami'ah, yaitu adanya unsur terhimpunnya beberapa akad dalam satu akad. Bedanya, dalammurakkab beberapa akad itu lebur menjadi satu akad (transaksi) yang memilikiimplikasi dan satu akibat hukum. Sedangkan dalam mujtami'ah, belum tentuterjadi peleburan akad. Artinya, dalam ijtimấ beberapa akad itu dapat meleburmenjadi satu akad dan dapat pula akad-akad tersebut berdiri sendiri-sendiri.

Dalam kondisi pertama, akad mujtami'ah dapat disebut dengandan merupakan salah satu bentuk akad murakkab, sedangkan dalam kondisi kedua (tidakmelebur menjadi satu), ia tidak dapat dikategorikan akad murakkab. Contohakad mujtami'ah adalah akad sewamenyewa (ijârah) dan jual beli (bay') yangdigabungkan menjadi satu meskipun kedua akad tetap eksis.

Dengan demikian, pengertian ijtimâ' (mujtami'ah) lebih luas dari padamurakkab, karena ijtima ${ }^{*}$ mencakup murakkab dan tidak murakkab. Ulama puntidak sekata atas penggunaan istilah ijtimâ' ini. ${ }^{6}$ Al-'Imrânî tampaknya membedakanistilah murakkab dan mujtami'ah seperti diuraikan di atas. Akan tetapi Nazih terlihat mempersamakan istilah murakkab dan mujtami'ah. Dalam beberapapembahasan, Nazih mencampuradukkan antara istilah akad murakkab danakad mujtami 'ah.Kedua, al-ta'addud. Kata ta'addud berarti berbilang dan bertambah. Ta'adduddalam terminologi akad adalah adanya tambahan jumlah syarat, akad,

${ }^{6} \mathrm{Al}$-imrani, Al-uqud al-Maliyah alMurakkabah, h. 53 
pelaku,harga, objek, atau sejenisnya. Istilah ta'addud lebih umum dari pada murakkab.Akad murakkab yang diartikan sebagai terhimpunnya dua akad atau lebihdalam satu akad, adalah makna dari terbilang (ta'addud) dalam akad. Bedanya, ta 'addud mengandung persoalan-persoalan yang tidak termasuk dalam tujuanakad murakkab, seperti berbilangnya dua pihak, atau dalam harga, benda, ataulainnya.

Karena itu ada perbedaan mendasar antara murakkab dan ta'addud,dimana murakkab mengandung konsekuensi satu, sedangkan ta'addud konsekuensinyabisa

berbilang.Ketiga, al-tikrâr. Al-tikrâr berarti berulang. Kata ini digunakan untuk menunjukkanadanya proses terhimpun atau terulangnya sesuatu. Sedangkan secaraterminologi altikrâr diartikan sebagai mengulangi sesuatu yang telah dilakukan.

Dalam hal akad, al-tikrâr berarti mengulangi akad yang telah dilakukansebelumnya.Bedanya dengan murakkab dalam akad, kalau al-tikrâr meskiberarti pula mengumpulkan tetapi maksud yang paling tetap untuk istilah iniadalah mengulangi akad yang sudah dilakukan dalam beberapa transaksi.Sedangkan dalam murakkab yang terjadi adalah terhimpunnya dua akad ataulebih menjadi satu akad atau transaksi.Keempat, al-tadâkhul. Altadâkhul secara bahasa berarti masuk (al-wulûj),masuknya sesuatu pada sesuatu yang lain, keserupaan beberapa hal dan salingmeliputi. Altadâkhul juga berarti masuknya suatu bagian pada bagian yang lain.

Arti terakhir ini lebih spesifik karena yang masuk adalah suatu bagian padabagian yang lainnya, sedangkan pengertian pertama lebih luas karena mencakupmasuknya sesuatu pada sesuatu yang lain. Sesuatu itu dapat berupa bagian atausuatu yang utuh.

Dalam terminologi fikih, altadâkhul diartikan sebagai terhimpunnya suatuhal tertentu dalam dua ketentuan hukum agama (syar'i) dan cukup hanyamelakukan salah satu ketentuan hukum tersebut pada umumnya boleh dipilih,namun akibat hukum keduanya atau salah satunya dapat tercapai. Daripengertian ini, al-tadâkhul mengandung pula makna pengumpulan. Akan tetapipengumpulan akad di sini dapat tercukupi dengan salah satu akadnya, tanpaakad yang lain.

Sementara pada murakkab, kedua akad atau lebih tidak bisadipisahkan satu dari yang lainnya. Keduanya digabungkan menjadi satu transaksitersendiri yang berakibat hukum pada objek transaksi dengan akibat yang satu.Jadi jelas, perbedaan mendasarnya bahwa murakkab meniscayakan leburnyadua atau lebih akad menjadi satu yang memiliki akibat hukum yang satu pula(dalam arti tidak bisa dipisahkan), namun akad-akad tersebut harus dilaksanakan.

Kelima, al-ikhtilâth. Kata ini memiliki makna yang sama dengan al-jam'u.Al-Ikhtilâth berarti terhimpun, terkumpul, insert (tadâkhul), dan melebur. Seperticontoh seseorang mencampurkan sesuatu pada yang lain, maka keduanya tercampuratau terkumpul. Tercampurnya dua hal itu bisa berakibat melebur menjadisatu sehingga kedua hal itu tidak bisa dibedakan seperti tercampurnya 
barang-barang cair, dan bisa juga dibedakan seperti dikumpulkannya suatu hewandengan hewan yang lain.

\section{Multiakad}

('uqûd

mukhtalithah) mengandung arti seperti akad murakkab,yaitu akadakad yang terhimpun dalam satu akad yang menimbulkan akibathukum satu akad. 'Uqûd mukhtalithah (contract mixed) adalah menghimpun beberapa akadmodern di mana satu akad melebur dengan akad lainnya. Dengan kata lain akadyang terdiri atas peleburan beberapa akad yang berbeda menjadi satu akad.Contoh akad yang mukhtalith adalah mengontrak rumah. Beberapa akad yangada di dalamnya adalah akad sewa untuk ruangan tinggal, akad bekerja sebagaipembantu, akad jual beli berkenaan dengan makanannya, dan akad wadî'ahberkenaan dengan penitipan barang-barang (amti'ah).

Akad mukhtalith digunakan pula untuk menyebutkan akad murakkab. Keduanyamemiliki makna yang sama, hanya berbeda dari sisi kedalaman maknanyasaja. Kata murakkab lebih spesifik dan khusus untuk multiakad ketimbang mukhtalith yang dapat pula mengandung arti yang lain.16 Baik akad murakkabmaupun mukhtalith dimaksudkan untuk menyatakan terhimpunnya beberapaakad menjadi satu akad dan berimplikasi hukum satu pada objek akadnya.Al-'Imrânî membagi multiakad dalam lima macam, yaitu: al-'uqûd almutaqâbilah,al-'uqûd almujtami'ah, al-'uqûd almutanâqidhah wa al-mutadhâdahwa al-mutanâfiyah, al-'uqûd almukhtalifah, al-'uqûd almutajânisah. Darilima macam itu, menurut dia, dua macam yang pertama yaitu al-'uqûd almutaqâbilahdan al-'uqûd almujtami'ah, adalah multiakad yang umum dipakai.Berikut penjelasan dari lima macam multiakad tersebut.Pertama, akad bergantung/akad bersyarat (al-'uqûd al-mutaqâbilah).Taqâbulmenurut bahasa berarti berhadapan. Sesuatu dikatakan berhadapan jikakeduanya saling menghadapkan kepada yang lain. Sedangkan yang dimaksuddengan al-'uqûd almutaqâbilah adalah multiakad dalam bentuk akad keduamerespon akad pertama, di mana kesempurnaan akad pertama bergantungpada sempurnanya akad kedua melalui proses timbal balik. Dengan kata lain,akad satu bergantung dengan akad lainnya. $^{7}$

Dalam tradisi fikih, model akad seperti ini sudah dikenal lama dan praktiknyasudah banyak. Banyak ulama telah membahas tema ini, baik yang berkaitandengan hukumnya, atau model pertukarannya. Misalnya antara akad pertukaran (mu'âwadhah) dengan akad tabarru', antara akad tabarru'dengan akad tabarru'atau akad pertukaran dengan akad pertukaran. Ulama biasa mendefinisikanmodel akad ini dengan akad bersyarat (isytirâth 'aqd bi 'aqd). ${ }^{8}$

Kedua, akad terkumpul (al'uqûd al-mujtami'ah). Al-'uqûd almujtami'ahadalah multiakad yang terhimpun dalam satu akad. Dua atau lebih akad terhimpunmenjadi satu akad. Seperti contoh, ,Saya jual rumah ini kepadamu dan sayasewakan rumah yang lain

\footnotetext{
${ }^{7}$ Imam Malik ibn Anas, Al-Mudawwanah al-Kubra, j. 4 (Bairut Dar: al-Shadir, 1323 H) Cet. I h. 26

${ }^{8} \mathrm{Al}$-imrani, Al-uqud al-Maliyah alMurakkabah, h. 57
} 
kepadamu selama satu bulan dengan harga lima ratusribu".

Multiakad yang mujtami'ah ini dapat terjadi dengan terhimpunnya duaakad yang memiliki akibat hukum berbeda di dalam satu akad terhadap duaobjek dengan satu harga, dua akad berbeda akibat hukum dalam satu akadterhadap dua objek dengan dua harga, atau dua akad dalam satu akad yangberbeda hukum atas satu objek dengan satu imbalan, baik dalam waktu yangsama atau waktu yang berbeda.Ketiga, akad berlawanan (al'uqûd al-mutanâqidhah wa almutadhâdahwa al-mutanâfiyah). Ketiga istilah ini, al-mutanâqidhah, al-mutadhâdah,

almutanâfiyah,memiliki kesamaan bahwa ketiganya mengandung maksud adanyaperbedaan. Tetapi ketiga istilah ini mengandung implikasi yang berbeda.Mutanâqidhah mengandung arti berlawanan, seperti pada contoh seseorangberkata sesuatu lalu berkata sesuatu lagi yang berlawanan dengan yangpertama. Seseorang mengatakan bahwa sesuatu benar, lalu berkata lagi sesuatuitu salah. Perkataan orang ini disebut mutanâqidhah, saling berlawanan. Dikatakanmutanâqidhah karena antara satu dengan yang lainnya tidak salingmendukung, melainkan mematahkan.Keempat, akad berbeda (al-'uqûd almukhtalifah). Yang dimaksud denganmultiakad yang mukhtalifah adalah terhimpunnya dua akad atau lebih yang memilikiperbedaan semua akibat hukum diantara kedua akad itu atau sebagiannya.

Seperti perbedaan akibat hukum dalam akad jual beli dan sewa. Dalamakad sewa diharuskan ada ketentuan waktu, sedangkan dalam jual beli sebaliknya.Contoh lain, akad ijârah dan salam. Dalam salam, harga salam harusdiserahkan pada saat akad ( $f \hat{\imath}$ al-majlis), sedangkan dalam ijârah, harga sewatidak harus diserahkan pada saat akad. Perbedaan antara multiakad yang mukhtalifah dengan yang mutanâqidhah,mutadhâdah, dan mutanâfiyah terletak pada keberadaan akad masing-masing.

Meskipun kata mukhtalifah lebih umum dan dapat meliputi ketiga jenisyang lainnya, namun dalam mukhtalifah meskipun berbeda tetap dapat ditemukanmenurut syariat. Sedangkan untuk kategori berbeda yang ketiga mengandung adanya saling meniadakan di antara akad-akad yang membangunnya .Dalam kajian ini, yang dimaksud dengan mutanâqidhah adalah: Pertama,dua hal yang tidak dapat terhimpun secara bersama (pada saat yang sama) dantidak pula dapat tiada pada saat yang sama, seperti hadirnya seseorang dan ketidakhadirannya. Jika seseorang hadir, maka tidak hadirnya tiada, tetapi jikatiada hadir yang ada, maka hadirnya tiada. Kedua, dua hal yang saling bertolakbelakang dan berlawanan, yang mana kehadiran yang satu menuntut ketiadaanyang lainnya, begitu pula sebaliknya. Seperti contoh antara menyerahkan dan menarik (salb). Ketiga, dua hal yang saling menafikan antara yang satu denganlainnya.

Sedangkan arti etimologi dari mutadhâdah adalah dua hal yang tidakmungkin terhimpun dalam satu waktu, seperti antara malam dan siang. Secara terminologis, mutadhâdah diartikan: Pertama, dua hal yang tidak dapat terhimpun pada saat yang sama, dan mungkin dapat hilang keduanya meskipunada perbedaan dalam hakekatnya, seperti 
antara hitam dan putih. Kedua, dua sifat yang saling mengganti (muta'âqibân) pada satu objek, namun tidak mungkin disatukan, seperti hitam dan putih. Ketiga, saling menerima dan menafikan secara umum dan dalam kondisi tertentu, seperti hitam dan putih. Keempat, sesuatu yang tidak mungkin dipersatukan dalam satu objek. Tampak jelas perbedaan antara mutanâqidhah dan mutadhâdah. Pada mutanâqidhah tidak mungkin dua hal bertemu dan keduanya tidak mungkin tiada pada saat yang sama, seperti pergi dan pulang. Sedangkan mutadhâdah dua hal tidak mungkin dipersatukan saling meniadakan seperti hitam dan putih,tetapi keduanya mungkin tiada pada saat yang sama. Sesuatu yang merah dapat menggantikan yang putih atau hitam.

Adapun arti dari mutanâfiyah adalah menafikan, lawan dari menetapkan. Mutanâfiyah diartikan sebagai: Pertama, mustahilnya penyatuan dua hal dalam satu waktu pada satu objek, seperti antara hitam dan putih, ada dan tiada. Kedua, satu tempat (objek) dengan berbeda keadaan, baik karena kondisi bertolak belakang seperti bergerak dan diam, atau kondisi berlawanan seperti berdiri dan duduk. Ketiga, mustahilnya kemungkinan bertemunya dua hal yang bertolak belakang dalam satu tempat, satu waktu, satu abjek. Seperti mustahilnya ada dan tiada bersatu pada satu objek, satu waktu, dan satu tempat. Dari pengertian di atas, para ahli fikih merumuskan maksud dari multiakad ('uqûd murakkabah) yang mutanâqidhah, mutadhâdah, dan mutanâfiyah, yaitu:

Pertama, satu hal dengan satu nama tidak cocok untuk dua hal yang berlawanan, maka setiap dua akad yang berlawanan tidak mungkin dipersatukan dalam satu akad. Kedua, satu hal dengan satu nama tidak cocok untuk dua halyang berlawanan, karena dua sebab yang saling menafikan akan menimbulkanakibat yang saling menafikan pula. Ketiga, dua akad yang secara praktik berlawanan dan secara akibat hukum bertolak belakang tidak boleh dihimpun.Keempat, haram terhimpunnya akad jual beli dan sharf dalam satu akad.

Mayoritas ulama Mâlikî berpendapat akadnya batal karena alasan ketentuan hukum kedua akad itu saling menafikan, yaitu bolehnya penundaan dan khiyâr dalam jual beli, sedangkan dalam sharf, penundaan dan khiyâr tidak diperbolehkan.Ada dua pendapat mengenai terhimpunnya jual beli dan ijârah dan jualbeli dengan sharf dengan satu imbalan ('iwadh). Pertama mengatakan kedua akad batal karena hukum dua akad berlawanan dan tidak ada prioritas satu akad atas yang lain karenanya kedua akad itu tidak sah. Pendapat kedua mengatakan, sah kedua akad dan imbalan dibagi untuk dua akad sesuai dengan harga masing-masing objek akad. Penggabungan ini tidak membatalkan akad.

Terhimpunnya dua akad atas objek yang memiliki harga berbeda dengansatu imbalan ('iwadh), seperti sharf dan bay' atau menjual barang yang dinyatakanbahwa akad telah mengikat sebelum serah terima, hukumnya sah, karenakeduanya dapat dimintakan imbalan sebagai harga masing-masing. Oleh karenaitu, kedua akad tersebut boleh dimintakan imbalan secara bersamaan. Menurutpendapat yang 
lain tidak sah, karena ketentuan hukumnya berbeda.

Dari pendapat ulama di atas disimpulkan bahwa multiakad yang mutanâqidhah,mutadhâdah, dan mutanâfiyah adalah akad-akad yang tidak boleh dihimpunmenjadi satu akad. Meski demikian pandangan ulama terhadap tiga bentuk multiakad tersebut tidak seragam. Kelima, akad sejenis (al-'uqûd almutajânisah). Al-'uqûd almurakkabah almutajânisah adalah akad-akad yang mungkin dihimpun dalam satu akad, dengan tidak mempengaruhi di dalam hukum dan akibat hukumnya. Multiakadjenis ini dapat terdiri atas satu jenis akad seperti akad jual beli dan akad jual beli,atau dari beberapa jenis seperti akad jual beli dan sewa menyewa. Multiakad jenis ini dapat pula terbentuk dari dua akad yang memiliki hukum yang samaatau berbeda.

\section{Konstruksi Hybrid Contract Pada Perbankan Syariah}

Konstruksi yang dimaksud dalam sub bab ini lebih fokus padapenerapan ragam hybrid contract (multiakad) yang diadopasi oleh lembagakeuangan syariah, utamanya bank syariah. Konstruksi yang ditonjolkanadalah fakta produk bank syariah yang memuat multi akad, baik secara eksplisit (sebagaiPenamaanproduk) maupun implisit (tidak dimunculkan sebagai nama produk) dan diimplementasikan di banksyariah. Pembagian multiakad sebagai perspektif ini menggunakan pendapat Abdullâh Al-'Imrâni (2006 : 69) sebagaimana tersebut di atas,yang membagi hybrid contract atau al'uqûd al-murakkabah atau multi akad dalam lima macam, yaitu
(1) al-'uqûd almutaqâbilah (akad bergantung/bersyarat), (2) al-'uqûd al-mujtami'ah (akad terkumpul), (3) al- 'uqûd al-mutanâqidhah wa almutadhâdah wa al-mutanâfiyah (akad berlawanan), (4) al-'uqûd almukhtalifah (akad berbeda), (5) al'uqûd al mutajânisah (akad sejenis). Dari lima macam itu, menurutnya, dua macam yang pertama; al-'uqûd al-mutaqâbilah (akad bergantung/bersyarat) dan al- 'uqûd al-mujtami'ah (akad terkumpul), adalah multiakad yang umum dipakai.

Oleh karena itu, akan diuraikan dan dikonstruksikan dua macamyang pertama; al-'uqûd almutaqâbilah (akad bergantung/bersyarat) dan al-'uqûd al-mujtami'ah (akad terkumpul), yang umum dipakai di bank syariah,baik secara eksplisit (dimunculkan sebagai nama akad yang dipakai) atauimplisit (tidak disebutkan tetapi senyatanya ada pada produk tersebut).

Data diperoleh dengan mengkombinasikan data primer pada tiga banksyariah yaitu Bank Mandiri Syariah, Bank Muamalat dan BNI Syariah,dengan cara wawancara; dan data sekunder yang diperoleh dengan caradokumentatif dari website ketiga bank syariah tersebut dan literaturpendukung.Dengan banyaknya produk yang ditawarkan oleh bank syariahtersebut, maka penulis mempersempit uraian dengan fokus pada duaproduk, yaitu Bank Garansi sebagai fungsi jasa (services) dan PembiayaanKepemilikan Rumah (PKR) sebagai fungsi pembiayaan (financing).

Keduanya pada ketiga bank syariah tersebut menerapkan dua multiakadyang telah dijelaskan di 
awal, yaitu al-'uqûd al-mutaqâbilah (akadbergantung/bersyarat) dan al'uqûd al-mujtami'ah (akad terkumpul).Dalam konteks produk Bank Garansi, ketiga bank syariah (BankSyariah Mandiri, Bank Muamalat dan BNI Syariah) memilikikecenderungan yang sama. Baginya, Bank Garansi merupakan suratpenjaminan yang dikeluarkan oleh bank dalam rangka menjaminnasabah untuk kepentingan pemilik proyek. Surat penjaminan inidiberikan untuk tujuan pengajuan tender, pelaksanaan proyek, uangmuka proyek dan pemeliharaan proyek.

\begin{tabular}{llr}
\multicolumn{1}{c}{ Bank } & Garansi (BG) \\
Jaminan & Pembayaran & yang
\end{tabular}
diberikanoleh Bank atas permintaan Nasabahnya, kepada pihak penerima jaminandalam hal Nasabah yang dijamin tidak memenuhi kewajibannya kepadapihak penerima jaminan. BG merupakan fasilitas non dana (Non FundedFacility) yang diberikan Bank berdasarkan akad Kafâlah bil Ujrah. Bankakan menerbitkan BG sejumlah nilai tertentu yang dipersyaratkan olehpihak penerima jaminan yang merupakan klien / mitra bisnis / counterpart dari Nasabah Bank untuk kepentingan transaksi / proyek tertentuyang akan dijalankan oleh Nasabah Bank.Bank Garansi adalah pelaksanaan pemberian jaminan dari bankatas permohonan nasabah untuk membayar sejumlah uang kepada pihaklain dengan persyaratan dan jangka waktu tertentu dengan syarat (1)mempunyai hubungan dagang atau kontrak dagang dengan pihak lain,dan (2) menyetorkan Marginal Deposit (MD) dan/atau memiliki fasilitaspembiayaan di BNI Syariah.

$\begin{array}{rrr}\text { Jenis } & \text { Bank } & \text { Garansi, pada } \\ \text { ketiga } & \text { bank } & \text { syariah }\end{array}$

tersebut,diterbitkan

untuk

kepentingan sebagai berikut :

1. Bid Bond / Tender Bond (Garansi

Penawaran)

Bank Garansi yang

diterbitkan dalam rangka mengikuti tender suatuproyek.

2. Performance Bond (Garansi Pelaksanaan)

Bank Garansi yang diterbitkan dalam rangka menjamin selesainyapelaksanaan pekerjaan atau untuk menjamin pembayaran atas barangyang telah diterima.

3. Advance Payment Bond (Garansi Uang Muka)

Bank Garansi yang diterbitkan dalam rangka menjamin selesainyasuatu pekerjaan setelah diterimanya pembayaran uang muka.

4. Maintenance Bond / Retention Bond (Garansi Pemeliharaan)

Bank Garansi yang diterbitkan guna menjamin pemeliharaanpekerjaan yang telah selesai dilaksanakan.Dalam hal penamaan produknya, ketiga bank syariah sama.Ketiganya menggunakan istilah Bank Garansi sebagai produk jasa ataulayanan (service) untuk coorporate customer (pelanggan perusahaan).

Demikian pula dalam hal penggunaan akad yang digunakanketiganya menggunakan akad kafâlah. Hanya Bank Muamalat yangmenggunakan istilah yang lebih tegas, yaitu kafâlah bi al-ujrah. Meskipunmemang sudah dimaklumi bahwa profit bank syariah dari produkberbasis akad kafalah adalah al-ujrah atau upah. Akad kafâlah dalamproduk Bank Garansi dari perspektif hybrid contract atau multi akad termasuk akad al-'uqûd almurrakabah al-mutaqâbilah (akad bergantung/bersyarat), di mana akad kedua merespon akad pertama,dan 
kesempurnaan akad pertama bergantung pada sempurnanya akadkedua melalui proses timbal balik. Dengan kata lain, akad satubergantung dengan akad lainnya.

Jika diteliti dari karakteristik produk Bank Garansi, maka akanterlihat akad apa yang mendampingi akad kafâlah tersebut. Jika proyekdigunakan untuk menjamin pembayaran dalam pembelian barang, makadidahului dengan akad salam atau akad hawalah (pemindahan hutang).Jika proyek digunakan sebagai jaminan mengikuti tender barang jadi,maka didahului oleh akad salam, tetapi jika mengikuti tender proyekkonstruksi (barang belum jadi), maka didahului dengan akad istishna'.Syarat umum yang dilakukan adalah nasabah yang mengajukan produk Bank Garansi harus memiliki minimal Marginal Deposit (MD) yangdipersyaratkan oleh bank syariah sebagai jaminan keseriusan penjaminandari bank syariah kepada nasabah pemohon.

Dalam konteks Pembiayaan

Kepemilikan Rumah (PKR), ketigabank syariah (Bank Syariah Mandiri, Bank Muamalat dan BNI Syariah)juga memiliki definisi dan cakupan kriteria garapan yang sama, yaitupembiyaan (1) bersifat konsumtif, (2) kepemilikan rumah, atau bangunanlain (termasuk rumah toko [ruko], rumah susun [rusun], rumah kantor[rukan], apartemen dan sejenisnya), bahkan tanah kavling, (3) pembelian,renovasi, pembangunan dan take over.Dalam hal penamaan produknya, ketiganya menggunakan istilahyang berbeda tetapi merepresentasikan produk pembiayaan (fungsifinancing) bank syariah.Bank Syariah Mandiri dengan nama produk"Griya BSM", Bank Muamalat dengan nama produk
"KPR MuamalatiB" dan BNI Syariah dengan nama produk "Griya iB Hasanah".

Demikian pula dalam hal penggunaan akad yang digunakanketiganya menggunakan akad murâbahah. Hanya Bank Muamalat yang(juga) menggunakan akad lain dalam produk ini yaitu akad al-ijârah wa alMusyârakah(musyârakah

mutanâqishah). Profit bank syariah yang dihasilkandari produk berbasis akad murâbahah adalah margin keuntungan. Profitbank syariah yang dihasilkan dari produk berbasis akad al-ijârah wa almusyârakahadalah alujrah atau upah.

Akad al-ijârah wa almusyârakah (Bank Muamalat) dalam produkPKR dari perspektif hybrid contract atau multiakad termasuk al'uqûd alMurakkabahal-mutajânisah (akad sejenis), di mana akad-akad yangmungkin dihimpun dalam satu akad, dengan tidak mempengaruhi didalam hukum dan akibat hukumnya. Multiakad jenis ini dapat terdiri darisatu jenis akad seperti akad jual beli dan akad jual beli, atau daribeberapa jenis seperti akad jual beli dan sewa menyewa. Multiakad jenisini dapat pula terbentuk dari dua akad yang memiliki hukum yang samaatau berbeda. Demikian pula, pada akad murâbahah (ketiga bank syariah)dalam produk PKR dari perspektif hybrid contract atau multiakadtermasuk pula al-'uqûd almurakkabah al-mujtami'ah (akad terkumpul),meskipun tidak secara ekplisit disebutkan.

Jika diteliti dari karakteristik produk PKR yang menggunakanakad al-ijârah wa al-musyârakah, maka akan terlihat jelas akad yang salingberdampingan secara eksplisit disebutkan yaitu akad al-ijârah dan 
akad almusyârakah,meskipun tidak beralih menjadi nama yang baru. Jika produkPKR menggunakan akad murâbahah, maka setidaknya ada tiga akadsejenis yang menyertai akad murâbahah, tetapi menyertai secara implisitdan tidak disebutkan secara jelas, hanya saja karakteristik akad tersebutsangat kuat. Akad tersebut adalah akad istishnâ', akad salam, dan akadhawâlah.Jika Pembiayaan Kepemilikan Rumah (PKR) berupa pembelianrumah jadi (dan sejenisnya), maka akad salam menyertai akad murâbahah,karena objek akadnya hanya tinggal menyerahkan saja. Sehingga dalamkonteks ini, ada sebutan salam paralel, di mana pemilik rumah jadimenjual kepada bank syariah, kemudian bank syariah menjual kepadanasabah pembeli rumah.

JikaPKRberupapembangunanatau renovasirumah(sejenisnya), maka akad istishnâ' yang menyertai akad murâbahah, karenaobjek akadnya masih harus diadakan (diwujudkan atau dibuat), setelahselesai, kemudian diserahkan. Sehingga dalam konteks ini, ada sebutanistishnâ' paralel, di mana pengembang (pembuat rumah atau developer)membuatkan rumah untuk bank syariah, kemudian setelah jadi, rumahtersebut dijual kepada nasabah yang minta dibuatkan rumah.Berbeda lagi jika PKR berupa take over (alih kredit ataupembiayaan), maka akad hawalah menyertai akad murâbahah, meskipundominasi akad menjadi akad hawâlah ketimbang akad murâbahah. Tetapimuatannya adalah bank membeli rumah milik bank lain (kredit ataupembiayaan pertama), kemudian dijual kembali kepada nasabah yang sama.

\section{KESIMPULAN}

Pertama, di era transaksi keuangan modern yang semakin kompleks, dibutuhkan design kontrak akad dalam bentuk kombinasi beberapa akad yang disebut dengan hybrid contract (multiakad), atau biasa disebut al-ukud al-murakkabah. Bentuk akad tunggal sudah tidak mampu meresponi transaksi keuangan kontemporer. Kombinasi akad zaman sekarang adalah sebuah keniscayaan, akad tunggal sudah tidak mampu lagi meresponi kasuskasus dan problem keuangan kontemporer. Untuk itu, perbankan syariah harus memperbaiki diri dalam peningkatan kualitas SDMnya dengan melaksanakan training dan workshop intensif mengenai inovasi produk.

Buku-buku teks fikih muamalah kontemporer menyebut istilah hybrid contracts dengan istilah yang beragam, yaitu al-ukudmurakkabah, al-ukud al mujtami'ah, adapula yang menggunakan istilah al-ukud almutajanisah. Menurut istilah fikih, kata hybrid contracts merupakan terjemahan dari kata Arab yaitu al-'uqudal-murakkabah yang berarti akad ganda (rangkap), akad yang bergabung, akad yang berhimpun, akad yang berkombinasi. Al-'uqud al murakkabah terdiri dari dua kata al-'uqud (bentuk jamak dari 'aqd) dan al-murakkabah. Kata 'aqd secara etimologi artinya mengikat, menyambung, atau menghubungkan (ar-rabt). Menurut Syamsul Anwar akad (perjanjian) adalah pertemuan ijab dan kabul sebagai pernyataan kehendak dua pihak atau lebih untuk melahirkan suatu akibat hukum pada objeknya.

Kata al-murakkabah (murakkab) secara etimologi berarti al-jam'u (mashdar), yang berarti pengumpulan atau 
penghimpunan.160 Kata murakkab sendiri berasal dari kata "rakkabayurakkibu-tarkiban" yang mengandung arti meletakkan sesuatu pada sesuatu yang lain sehingga tersusun dengan baik, ada yang di atas dan yang di bawah.Sedangkan murakkab menurut pengertian para ulama fikih (dalam konteks akad) ialah himpunan beberapa akad sehingga disebut dengan satu nama akad.

Dalam teorinya terdapat beberapa penggabungan akad yang dilarang. Dalam hadist, Nabi Muhammad SAW secara jelas menyatakan dua bentuk hybrid contract yang dilarang, yaitu hybrid contracts dalam jual beli (bay') dan pinjaman serta dua akad jual beli dalam satu akad jual beli dan dua akad dalam satu transaksi. Dalam sebuah hadist "Dari Abu Hurairah, Rasulullah melarang jual beli dan pinjaman". (HR. Ahmad), yang artinya salah satu yang akad yang dilarang yaitu menggabungkan akad bay' (jual beli) dan salaf (pinjaman).

Sebagai contoh Ali meminjamkan (qardh) sebesar 1000dirham, lalu dikaitkan dengan penjualan barang yang bernilai 900dirham, tetapi harga penjualan itu tetap harga 1000dirham. Seolah-olah Ali memberi pinjaman 1000dirham dengan akad qardh, dan menjual barang seharga 900dirham, agar mendapatkan margin 1000dirham. Disini Ali memperoleh kelebihan 100dirham.163Ibn Qayyin berpendapat bahwa Nabi Muhammad melarang hybrid contracts antara akad salaf (memberi pinjaman/qardh) dan jual beli, untuk menghadiri terjerumus kepada riba yang diharamkan. Namun jika kedua akad itu terpisah (tidak tergantung, muallaq) hukumnya boleh.Larangan kedua yaitu penghimpunan dua akad jual beli dalam satu akad jual beli didasarkan pada hadist Nabi Muhammad yang artinya: "Dari Abu Hurairah, "Rasulullah melarang jual beli dan pinjaman"., (HR. Malik)

Banyak tafsir tentang hadist ini, pendapat yang dipilih adalah pendapat yang mengatakan bahwa akad demikian menimbulkan ketidakjelasan harga dan menjerumuskan ke riba. Misalnya seorang penjual berkata kepada orang banyak di sebuah jamaah, "Saudara-saudara, saya menjual barang ini seharga satu juta rupiah, jika dibayar tunai, dan satu juta dua ratus ribu rupiah jika cicilan setahun". Lalu seorang yang hadir berkata, "Saya beli". Disini telah terjadi ijab dan kabul, sementara harganya tidak jelas, karena dipilihkan dua macam harga.164

Penafsiranlain, seseorang menjual suatu barang dengan cicilan, dengan syarat pembeli harus menjual kembali kepada orang yang menjual itu dengan harga lebih rendah secara kontan. Akad al-'Inah seperti ini merupakan hilah dari riba. Inilah yang disebut bay' al-'Inah. Menurut Ibnu Qayyim, penafsiran inilah yang paling kuat.

Kedua, Konstruksi hybrid contract model pada bank syariah lebihmenganut pada (1) kontruksi al'uqûd al-mutaqâbilah (akad bergantungatau bersyarat) yaitu multiakad dalam bentuk akad kedua merespon akadpertama, di mana kesempurnaan akad pertama bergantung padasempurnanya akad kedua melalui proses timbal balik. Konstruksi inipada bank syariah diimplementasikan pada produk Bank Garansi (BG);dan (2) konstruksi al-'uqûd al-murakkabah 
al-mutajânisah (akad sejenis)yaitu akad-akad yang mungkin dihimpun dalam satu akad, dengan tidakmempengaruhi di dalam hukum dan akibat hukumnya. Multiakad jenisini dapat terdiri dari satu jenis akad atau dari beberapa jenis. Multiakadjenis ini dapat pula terbentuk dari dua akad yang memiliki hukum yangsama atau berbeda. Konstruksi ini pada bank syariah diimplementasikanpada produk Pembiayaan Kepemilikan Rumah (PKR).

\section{DAFTAR PUSTAKA}

Anto Danjan, "Pengantar Metode Statistik Jilid I", Pustaka LP3ES Indonesia, anggota IKAPI, 1986.

Abdullah, Ru'efah dan Sohari Sahrani, 2011, Fikih Muamalah, Cet. I; Bogor: Ghalia Indonesia.

Al-Asqani, Abu Fadli bin Ali Hijr, 1409/1989 M, Bulughul Maram, Bab al-Hiwalah Wa adh-Dhamman Beerut: Daarb aal-Fikr.

Antonio, Muhammad Syafii, 2009, Bank Syariah Teori ke Praktik, Jakarta: Tazkia.

Arifin Zainul, 2006, Dasar-Dasar Manajemen Syariah, cet 4, Jakarta: Pustaka Alvabet.

Ascarya, 2011, Akad dan Produk Syariah, cet 3, Jakarta: Rajawali press.

Anwar, Syamsul, 2007, Hukum Perjanjian Syariah Studi Tentang Teori Akad dalam Fikih Muamlaat, Jakarta: Raja Grafindo Persada.

Dewan Syariah Nasional-MUI, 2000, Himpuan Fatwa DSN-MUI,
Cet ke-3, edisi revisi, Ciputat: CV.Gaung Persada.

Al-Minawi. 1410. al-Ta'arif, ed. M. Rhidwan al-Dhayah, cet 1 . Beirut-Damaskus: Dar alFikr al-Mu'ashir

Karim A. Adiwarman, 2001, Ekonomi Islam Suatu Kajian Kontemporer, Jakarta: Gema Insani.

, 2004, Bank Islam: Analisis Fiqh dan Keuangan, Jakarta: PT. Raja Grafindo Persada.

Haroen, Nasrun, 2000, Fiqh Muamalat, cetakan 1, Jakarta: Gaya Media Pratama.

Hasbi ash-Shidiqi, Tengku Muhammad, 2001, Koleksi Hadis dan Hukum, edisi 2, cet 3, Semarang: PT. Pustaka Riski Putra IAI, "Akuntansi Perbankan Syariah", PSAK 59, 2002.

Boediono (1985), Ekonomi moneter, seri sinopsis pengantar ilmu ekonomi no.5 BPFE, Edisi Ketiga, Yogyakarta

Fadhila, Dewi Rohma (2004), Pengaruh Tingkat Bagi Hasil dan Suku Bunga Bank Konvensional Terhadap Simpanan Mudharabah Studi Kasus Bank Syariah Mandiri. Skripsi S1, Fakultas Ekonomi, Universitas Islam Indonesia, Yogyakarta.

Cahyono, A. 2009. Pengaruh Indikator Makroekonomi

Terhadap DPK dan Pembiayaan pada Bank Syariah Mandiri. Thesis. PSKTTI UI. Jakarta

Budiati, A. N. 2007. Pengaruh Tingkat Suku Bunga Dan Tingkat Bagi Hasil Terhadap Pendanaan Pada Bank Muamalat Indonesia. Skripsi. 


\begin{tabular}{llr} 
& $\begin{array}{l}\text { Universitas } \\
\text { Jakarta. }\end{array}$ & Indonesia. \\
Bank & \multicolumn{1}{c}{ Mandiri } & Syariah \\
& (http://www.syariahmandiri.c \\
o.id) & Muamalat \\
Bank & & Syariah \\
& (http://www.muamalatbank.c \\
BNI & om) & Syld \\
& (http://www.bnisyariah.co.id
\end{tabular}

